\title{
Aspects of Community-based Adult Education Activities in Naluei Ward of Mongu District, Zambia
}

\author{
Stephen Banda, Anolt L.H. Moonga, Phyllis I. Sumbwa \\ The University of Zambia, School of Education, Department of Adult education and Extension Studies \\ *Corresponding Author: Stephen Banda, the University of Zambia, School of Education, Department of \\ Adult education and Extension Studies
}

\begin{abstract}
The genesis of this study was from the realization that little was known about aspects of community-based adult education activities in Zambia. In Africa, adult education deals with cross-cutting issues that help adult people operate effectively and efficiently to achieve individual, family, community and societal sustainable development through meaningful active contribution. Adult education helps change adults' lives to attain their full potential such as through acquisition of knowledge, skills, positive attitudes, values and citizen awareness.

This research was a case study conducted in Naluei Ward of Mongu District, Zambia whose objectives were to: identify the community-based adult education activities in Naluei Ward; establish participation levels of community members in community-based adult education programmes in Naluei Ward; establish the types of community-based adult education in Naluei Ward; and identify challenges members of the Naluei Ward community face in the community-based adult education activities.
\end{abstract}

The data collection methods used was focus group discussions, interviews and questionnaires. Focus group discussions and semi-structured interviews were conducted among the youths, middle aged as well as the elderly men and women in the community while questionnaires were distributed to community development officers, local community leaders and administrators. Respondents were allowed to exercise their right to voluntarily accept or refuse to participate in the study. They were also assured of confidentiality and anonymity. Data was analyzed using both qualitative and quantitative methods. Quantitative data was presented in percentages while qualitative data was organized and presented according to identified themes and sub-themes.

The findings of this study identified some community-based adult education activities in the Naluei Ward; established low participation levels of community members in Naluei Ward; established that only non-formal and informal types of community-based adult education were found in Naluei Ward; and identified some challenges faced in the process of facilitating community-based adult education in Naluei Ward.

The study concludes that since the success of community-based adult education has not yet resulted in an equally successful implementation, it is time to take stock of what has been achieved and look at what should be done to achieve community-based adult education for all, not just a few.

Keywords: Adult education, community, community-based activities, community-based adult education

\section{INTRODUCTION AND BACKGROUND}

This paper is based on a study conducted in Naluei Ward of Nalikwanda Constituency in Mongu District, Western Province of Zambia in 2016. The study had its genesis from the realization that little was known about aspects of community-based adult education activities in Naluei Ward of Western Province of Zambia. Naluei Ward of Nalikwanda Constituency is located in a rural area along Lusaka-Mongu Road. This road is a very important infrastructure attraction in Western Province as it links the province to Lusaka, the capital city of Zambia.

Although there is no universal definition, in this paper, community-based adult education may be considered to be a concept used by adult educators and other change agents or facilitators and their adult learners in communities to enhance the concepts or issues being taught and learnt by connecting them to personal, first-hand experiences and familiar, accessible examples (Victorino-Soriano, 2016). In this way, community-based learning is often positioned as an alternative to more traditional forms of learning in which learners may read or learn about people, places, or events they have never experienced or be introduced to concepts that can only be understood in abstract. 
Community-based learning is also motivated by the belief that all communities have intrinsic educational assets and resources that educators can use to enhance learning experiences for learners (Power, et al., 2011). A common defining feature is that programmes and activities are developed in dialogue with communities and participants. The purpose of community-based adult education is to develop the capacity of individuals and groups of adults through their actions, the capacity of communities, to improve their quality of life. Central to this is their ability to participate. The Western Province of Zambia has a strong history in the promotion of community-based adult learning activities from pre-colonial, colonial to modern times. Besides through indigenous education systems, community-based adult education activities in the Western Province of Zambia may be traced way back to Christian missionaries' times in 1883organized by Fredrick Anort at Lealui in Barotseland (present Western Province's Barotse plains) with three adult learners as a tool for the social and cultural transformation of indigenous cultures. As Mtonga (2016) puts it, in many parts of Africa, adult education deals with cross-cutting issues that help adult people operate effectively and efficiently to achieve individual, family, community and societal sustainable development through meaningful active contribution. Adult education helps change adults' lives to attain their full potential such as through acquisition of knowledge, skills, positive attitudes, values and citizen awareness. Moreover, it is said that 'education is one of the most important drivers for ending poverty and boosting shared prosperity' (King, 2013: 34).

Community-based adult education can safely be said to be as old as the human beings themselves. Its existence has been seen from the kind of activities that adult people engage themselves in since time immemorial. These activities would include sustainable livelihoods, marriage counselling, weather forecasting and many other community activities (Banda, et al., 2015).Adult education in Africa dates back to traditional African society where it used to secure the survival of the community. Enveloped in the survival drive were the community's values, knowledge, morality, skill acquisition and various forms of training. Like the rest of traditional education, adult education then was a lifelong process essentially culture-propelled and community-based. It was an important bridge between the past and present with a shuttle to the future (Avoseh, 2000).Community-based adult education, therefore, serves as an instrument for social change, which contributes to sustainable development. Development implies positive change. Adult education has a symbiotic relationship with the environment in which it occurs. It tends to respond to social change and further social change (Banda, 2011). Indeed adult education can and should play an integral role in improving not only individuals' lives but also improving society; adult education can promote change as well as respond to it.

In adult education, it has been very common over the years for literacy programmes to combine literacy training with some form of occupational training and income-generation activities. In contemporary period, community-based adult education in Africa has particular emphasis on facilitating acquisition of new skills, values, attitudes and knowledge of the social, economic, environmental, cultural, and political environment in developing and conducting adult education programmes for individuals and groups in communities. There is a great deal of learning that occurs in our local communities. As Avoseh (2000) puts it, community-based adult education rests on the assumptions that education makes significance difference in the lives of people and increases their worth, responsible roles (in terms of employment, self-employment and decision making) they can play in society, their dignity and potential for development. Due to rapid technological advances and changes, there will be quick shifts in the world of work, business, and general social life which have implications on the kind of education required and, therefore, new competencies needed (VictorinoSoriano, 2016).

Community-based adult education is one of the critical keys to community development. Although there are many ways of defining it, community development can be seen as the process of people working together on a local level to improve the economic, social, cultural and environmental conditions in a community. This process includes the conception of ideas as well as the planning, implementation, monitoring, and evaluation of projects to improve the living standards of people in those communities. Community development's origins in Africa and indeed Zambia are traceable to the colonial era (Noyoo, 2008) when efforts aimed at developing the colonies through projects such as literacy training and nutrition, for example, were mooted.

Furthermore, modernization theories contend that community-based education is a means to achieve development goals at the rural communities level (Sundaram, 2002). Adult education may thus be seen 
as helping adult people to absorb the rapid social change associated with the transition from simple societies to modern democratic society with its fundamental economy and maximum social mobility. Adult education improves human resources on which national development plans depend. Generally, community-based adult education is a means by which people can enrich and enhance their lives and that of their communities through playing responsible roles and living responsibly. However, little of community-based adult education activities in Zambia have been documented. Hence, this study attempted to fill in the knowledge gap.

\section{Statement of the Problem}

The University of Zambia through the Department of Adult Education and Extension Studies has been facilitating community-based adult education activities in all provinces of Zambia for a number of years. The department has provincial offices through which community-based adult education activities are facilitated, mostly in collaboration with other stakeholders like Government line ministries and Non-Governmental Organizations. The University of Zambia's provincial office for Western Province is located in Mongu District.

Although the University of Zambia has been facilitating community-based adult education activities in the Western Province of Zambia since the extension education centre was established in 1967, it seems no study has been conducted to document the activities and their impact on communities. This is an aspect of concern. This study attempted to fill this knowledge gap.

\section{Purpose of The Study}

This study sought to investigate community-based adult education activities in Naluei Ward of Mongu District in the Western Province of Zambia.

\section{RESEARCH OBJECTIVES}

The objectives of the study were to:

i) Identify the community-based adult education activities in Naluei Ward;

ii) Establish participation levels of community members in community-based adult education programme sinnaluei Ward;

iii)Establish the types of community-based adult education in Naluei Ward; and

iv) Identify challenges members of the Naluei Ward community face in the community-based adult education activities.

\section{RESEARCH QUESTIONS}

In order to achieve the objectives, the study sought to answer four major questions. These were:

i) What community-based adult education activities are found in Naluei Ward?

ii) To what extent do community members innaluei Ward participate in community-based adult education programmes?

iii) What types of community-based adult education are found in Naluei Ward; and

iv) What challenges do community member's of naluei Ward face in the community-based adult education activities?

\section{SigNifiCANCE OF THE STUdY}

The findings from the study may help community-based adult education providers to improve their implementation methods and strategies. The future of our urban and rural communities will depend on an educated citizenry. Community-based adult education can provide a mechanism for opportunity to engage in lifelong learning, if properly cultivated. Through this study, communities in the country may become aware of evidence and contribution of community-based adult education activities in Naluei Ward of Mongu District in the Western Province of Zambia. Naluei Ward is in a rural area at the boundary of Mongu and Luampa districts. The findings of the study may also show the significance of community-based adult education and its potential to enhance sustainable development in Naluei Ward and surrounding areas of Monguand Luampa districts. Community-based adult 
education is very important for rural development in any society and it would add value in the process of sustainable development in Zambia.

The data collected may also benefit the community members of the Naluei Ward by providing them with useful literature that may enable them fully participate to come up with solution strategies to meet some challenges affecting their communities. The findings may also contribute information to the existing body of knowledge on the significance of community-based adult education.

\section{REVIEW OF LITERATURE}

Additional information on the subject matter in this study was obtained from past written materials. Literature search was employed because it offers the greatest opportunity to benefit from the experience of others who have conducted similar studies. Documents consulted include books and journals, annual reports for various organizations, government policy documents, international and local publications, and the Internet. The literature reviewed in detail relates to four major issues in line with the study objectives:

i) Community-based adult education activities;

ii) Participation levels of community members in community-based adult education;

iii) Types of community-based adult education; and

iv)Challenges faced by community members to access community-based adult education.

The summarized literature review in this article discusses what has been studied by others elsewhere and outline knowledge gaps which this study may fill. Literature reviewed here shows that very little is directly discussing studies conducted on the aspects of community-based adult education activities in Naluei Ward of the Mongu District in the Western Province of Zambia in particular, which this study focused on.

\subsection{Significance of Community-based Adult Education in Society}

Community-based adult education is a cardinal element of community development in any society. In simple terms, community-based adult education is the broad set of teaching and learning strategies that enable the youth and adults to learn what they want to learn from any segment of the community to improve quality of their lives and communities. In other words, community-based adult education could be described as an educational process by which individuals (in this case adults) become more competent in their skills, life values, attitudes, and concepts in an effort to live in and gain more control over local aspects of their communities through democratic participation. Hamilton and Cunningham (1989: 439) suggest that 'community-based adult education operates on the assumption that a given community, whether urban or rural, has the potential to solve many of its own problems by relying on its own resources and by mobilizing community action for problem resolution.' The scholars continue by indicating that the aims and purposes of community-based adult education usually are directly related to specific community issues such as career training, sustainable livelihoods, environmental concerns, basic education, health education, ethnic history and culture, governmental policies, and civic and political education.

In addition, Freire (1986) emphasizes the necessity of learning new skills and knowledge about existing social problems. Learning is the dominant factor and as a result propels community-based adult education activities towards definite educational outcomes. Compton and McClusky (1980) did not use the term 'community-based education' but instead used the phrase 'community education for development' and defined it as 'a process whereby community members come to identify their problems and needs, seek solutions among themselves, mobilize the necessary resources, and execute a plan of action or learning or both. This educative approach is one in which community is seen as both an agent and objective, education is the process, and leaders are the facilitators, in inducing change for the better' (p.229). From this perspective it could be suggested that community-based adult education's primary purpose is to meet the unique needs of the community it serves, as a whole and individually. Community-based adult learning programmes are planned and evaluated against agreed outcomes. Some programmes provide accredited qualifications and others offer first-step learning. All learners are encouraged to complete an individual learning plan setting out their learning goals and how these will be achieved. 
In addition, community-based adult education generates and utilizes available resources and skills, as well as those untapped skills and resources, to meet the varied needs of the community and those of its residents. The community-based adult learning facilitated through community-based adult education is mostly targeted around the following key themes:i) family learning; ii) parenting; iii) health and well-being; iv)literacy and numeracy; v) employability and entrepreneurship development; and vi) personal and community development to achieve quality sustainable life in society.

\subsection{Participation Levels of Community Members in Community-based Adult Education Programmes}

The term participation is commonly understood to mean 'taking part'. Gboku (2007) shows that people attach different meaning to the term participation to include control, consultations and information to those involved in programmes. Participation of adult learners is a key factor for the successful developments, implementation and evaluation of community-based adult education programmes because their views, suggestions and requests need to be integrated into the development of programmes so as to raise their motivation and commitment to participate in the programmes. They should also be involved in making decisions on the programme goals, course content, resources and logistics of training. Moreover, Gboku (2007) suggests that the participation of adult learners can be increased by the involvement of all the stakeholders who should include the community, the learners, the would-be-learners, beneficiaries like families, employers and funding partners in a number of ways. Hence, the programme developers should involve adults in communities in the identification and evaluation of educational needs of the learners and in setting the educational goals for the community-based adult education programmes. The programme administrators should involve community members in identifying and solving problems that act as barriers to increasing participation to all stages of development and implementation of community-based adult education programmes. Further, all stakeholders should be involved in decision making and in creating the infrastructures that will lead to creating ownership, besides accomplishing the goals and sustainability of the community-based adult education programmes. The community at large and the learners need to be involved in identifying their needs, if they are to be motivated in participating.

Every person is a member of some kind of community and each, whether deliberately or unintentionally, participate in some aspect of learning provided within their social milieu (UNESCO, 2006). Communities are diverse entities. It is through this diversity that adult learners find educational opportunities to engage in purposeful learning. Further, according to a classical study in communitybased adult education conducted way back by Dale and Tyler (1934), seven major values of participation in community-based adult education literacy programmes were identified as cardinal to enhance community development in society. The study stated that a literate person is able to learn about community activities and trends and the forces that make for or retard progress by studying social problems.

Another important value is that a literate person is able to understand civic rights, and obligations by knowing about and observing regulations, participating in group discussions and in the efforts to ensure civic improvement and voting without seeking for help. The other value is that a literate individual is able to comprehend the affairs outside their own society through learning about issues and events far and near, and the natural and social forces that influence life. Lastly, being literate helps individuals to satisfy cultural and religious aspirations through understanding cultural customs, reading sacred literature and participating in various cultural and religious activities. From the values stated, it is clear that those who provide literacy training have almost an unlimited opportunity to increase the efficiency and enrich the experiences of their learners to cope with various challenges they may encounter in life.

Therefore, to support the study by Dale and Tyler (1934) adult literacy programmes generally aim at providing knowledge and skills to adults and out of school youth to improve their quality of life and contribute effectively to national development. The programmes cover two main areas namely: the basic literacy and the post literacy programmes. On the other hand continuing education programmes build on previously acquired knowledge and skills for purposes of certification, self-improvement and more effective participation in community and national development. These programmes provide opportunities for the youths and adults to integrate into the formal education and to improve their 
knowledge and technical skills. The programmes aim at building capacity by giving knowledge, skills, attitudes and values which enable people to engage in gainful employment, create employment through entrepreneurship development and improve on the quality of life. Hence, participation of adult population and youths in these forms of community-based adult education is important for the individual, community and country's socio-economic development. Participation of adult population in community-based adult education has continued to pose a major challenge in the world. The global monitoring report (UNESCO, 2006) on the progress towards attainment of Education for All (EFA) goals indicated that, attainment of the EFA goals for literacy has been relatively neglected. According to the report (UNESCO, 2006) five years after 164 countries agreed on the Dakar framework for action, most attention has been devoted to the three EFA goals that concern the extension and improvement of formal elementary education systems. The other three EFA goals have been relatively neglected.

Participation of adult learners is a key factor for the successful developments, implementation, monitoring and evaluation of community-based adult education programmes. However, a number of researchers and interest organizations have noted that participation of adult population in communitybased adult education has continued to pose a major challenge in the world. Low participation of learners in adult education programmes has been a major problem all over the world (Sumbwa, 2013; UNESCO, 2006).

\subsection{Types of Community-based Adult Education Activities}

As part of lifelong learning, community-based adult educational opportunities exist in each community in three distinct but often intertwined educational forms: formal, non-formal, and informal. Each process is a valid means of assisting lifelong learners in acquiring and meeting their educational needs. This implies that lifelong learners can make choices in fulfilling their educational concerns and desires in a multitude of ways.

Lifelong learning suggests life span learning and the transformation process that takes place from birth to death (Smith, 1982). Lifelong education can be defined as a process of deliberate and unintentional opportunities that influence learning throughout the life span. Dave (1976) states that lifelong education 'seeks to view education in its totality. It covers formal, non-formal, and informal patterns of education, and attempts to integrate and articulate all structures and stages of education...It is a process of accomplishing personal, social, and professional development throughout the life span of individuals in order to enhance the quality of life of both individuals and their collectives' (p. 35). From this definition, lifelong education is incorporated into every aspect of society through the multitude of institutions and individuals within that society. It is deeply rooted in the social circumstances which determine the motives of human action (Victorino-Soriano, 2016). In simple terms, lifelong education refers to holistic learning for life and work.

Lifelong education does not take place in a vacuum but involves human beings and the society in which they live. If lifelong education is to be a reality, profound implications of a psychological as well as a social nature must be considered (Smith, 1982; Wain, 1987). Lifelong education is education for a changing world. As part of lifelong learning, community-based adult education is cardinal to national development as it promotes the acquisition of relevant knowledge, positive attitudes and life skills among adults, youths, and facilitates the workers adaptation to new technologies and production skills.

Hence, this would facilitate the development of economic opportunities such as through improved entrepreneurship and production skills. Moreover, community-based adult education helps disadvantaged groups through promotion of self-confidence, positive values and awareness among individuals and communities with regard to their rights and civic duties. Thus, such inclusive learning for all would imply that all would strive to acquire knowledge, attitudes, values and skills we need to lead healthy and productive lives, secure meaningful employment, create employment, create wealth and positively contribute to sustainable development in society.

The concepts of community-based adult education and lifelong learning when merged utilize formal, non-formal, and informal educational processes. Through this merger, it has the potential to impact individuals, groups, and communities in the way they live, inform, and educate themselves. It can serve as a mechanism for self-fulfillment as well as for social, political, and psychological 
empowerment. When community-based education and lifelong learning is connected both conceptually and in practice, a unique relationship is developed that gives individuals and communities a sense of hope and dignity, a sense of responsibility for their own communities and lives, and a sense of voice within the social and political arenas. The connection suggests an inclusionary and liberating significance for individuals, groups, and communities.

\subsubsection{Formal Community-based Adult Education}

Formal learning refers to what takes place in the education and training system of a country. It is official, structured, organized by public organizations or recognized private institutions and results with formal certification and formal level of qualification which is recognized by relevant national educational authorities. Formal education is usually organized as full-time education and is organized as a continuous process with defined stages. Formal education encompasses primary, lower and upper secondary education, higher and university education that culminate in the achievement of a degree or a professional qualification or diploma or a recognized certification as well as adult education programmes.

In other words, this category of community-based adult education consists of for-profit and nonprofit bureaucratic organizations within the community who have as their primary function the delivery of formal education in which youth and adult learners may participate. The goal of the organization or institution is to provide some type of credential such as a certificate, diploma or degree. Because of the nature of the settings, instructors or teachers are professional educators who hold expertise in the area of specialization. Learners in formal community-based adult education settings have little control over what is taught and how it is taught. Educators make value and prescriptive judgments of what is appropriate for learners to acquire within their educational pursuits.

\subsubsection{Non-formal Community-based Adult Education}

Non-formal community-based adult education belongs somewhere between the formal and informal types. As in formal education, people using non-formal methods adopt planned and organized camps. But the education procedures are less tightly controlled than those of formal systems. In other words, non-formal education is any type of structured and organized learning which is institutionalized, intentional and planned by an educational provider, but which does not lead to formal level of qualification recognized by the relevant national education authorities. This has made many people and organizations cling to a myth that non-formal education is inferior and mostly meant for the vulnerable groups in society. However, non-formal education is not inferior, but just a component of the three major types of education that are complementary.

People of various age groups can participate in non-formal education which can be offered through courses, workshops, public lectures or seminars. A number of organizations and agencies can be viewed as non-formal community-based adult education providers, although education is a secondary or allied function to their primary mission or purpose. In Zambia, the Young Men's Christian Association (YMCA) or Young Women's Christian Association (YWCA), some institutional or cooperative extension units and clubs, religious institutions, health institutions, service clubs, voluntary organizations, business and industry human resource development programmes, correctional institutions, libraries, museums, senior citizen organizations, and a plethora of other community-based agencies are examples of such non-formal community-based adult educational providers. In these settings learners are more likely to participate voluntarily and are not seeking any type of credential or degrees but may receive in some cases a certificate of participation or completion. In some countries, governments are becoming involved in a bid to provide some combination of literacy and skill development relevant basic education for hard-to-reach youths and adults in vulnerable situations, such as programmes for street 'children' (Victorino-Soriano, 2016).

Adult learners participating in non-formal community-based adult education retain some control over what they want to learn as well as when, how, and where the learning takes place. The non-formal settings range from non-structured to structured (Wain, 1987). The instructors may or may not be professionally trained but overall seem to be quite successful in helping learners reach their educational goals. 


\subsubsection{Informal Community-based Adult Education}

Informal community-based adult education, on the other hand, involves people learning while they go about their daily lives. Informal learning takes place whether or not there is a deliberate choice by the adult learner and is realized in the performance, by any person, of activities in everyday situations and interactions that take place in them, within the context of work, family life, business and leisure. It takes place without external support and is not institutionalized.

This category encompasses the vast majority of education that takes place for adult learners within community structures. Informal community-based adult education is independent of institutional and organizational provider ship. The community itself is the instrument of education and learners are guided by their own desires and learning processes. Learning within this context may be deliberate or fortuitous, but is always personally meaningful to the learner. Informal community-based education is characterized by interaction between human and material resources. The adult learners are in complete control over how, what, and where the learning will occur. Although the learners may consult with others concerning their inquiry, in most cases a professionally trained educator is absent. The community serves as the educator as well as the learning resource and laboratory. When people try to find out information or to gain skills on their own initiative without a teacher, this is also a part of informal education. For this, they may visit village group gatherings (insaka), visit other people's farms, read a book, search on the Internet, watch videos, visit a library, or museum. They may watch a television or cinema show or a videotape or listen to a radio programme. They do not have to pass tests or examinations. There are many other ways to learn such education like on the job learning.

\subsection{Challenges Associated with Community-based Adult Education in Africa}

In many studies conducted in Africa, it has been established that there are many challenged associated with the provision of community-based adult education programmes (see Sumbwa, 2013; Gboku, 2007; Ayot, 1999).In spite of the region's immense human and natural resource potential, some threequarters of the world's poorest governments and people are found in Africa (UNESCO, 2006). The poor state of many African governments coupled with low political will could be said to be a major factor and challenge to adequately provide and enhance quality community-based adult education programmes. The argument is that what may be easy to reach in one country may be very difficult in another one. Even within countries, there are often big differences between opportunities in urban and rural areas, between rich and marginalized adults and youths, as well as ongoing inequalities between male and female access. For community-based adult education to be everywhere and for every adult at all times, there is great need to enhance quality community-based adult education. This would enable us achieve holistic sustainable development and realize the world we need, not just want.

Moreover, much as decentralization may be a good aspect in the development of good governance, it seems to offer a challenge in the development of provision of community-based adult education in many African countries (Gboku, 2007). When literacy or non-formal education programme implementation is decentralized, it often has the effect of making the sector more invisible. What might havebeen visible at the central level vanishes when the literacy department is displaced to district or local primary education department offices. Often these are headed by managers from the formal schooling sector who are not so sensitized to adult education needs.

\section{Methodology}

In 2016, a study to investigate the social value of community-based adult education activities around Naluei Ward in Mongu District of the Western Province of Zambia was undertaken by a team of researchers from the University of Zambia. This research was a case study. A case study seeks to describe a unit in detail, in context and holistically (Yin, 2014). This enables the researchers to involve an in-depth examination of the study in a naturalistic context. The study employed more qualitative than quantitative approach in data collection and analysis. This more qualitative research focus is in keeping with the participant-centred philosophy of community-based education (Power, et al., 2011). The study employed both qualitative and quantitative approaches in order to triangulate the data collected.

\section{STUDY LOCATION}

The study was conducted in Naluei Ward area located in a rural area at the boundary of Mongu and Luampa districts in the Western Province of Zambia. Much of the Western Province of Zambia is 
covered by the Kalahari sands. The Kalahari sands found in the desert also cover much of Western Zambia where we find Naluei Ward. However, much of Naluei Ward has an accessible terrain which helped the team of researchers reach many remote areas.

\section{TARgET POPUlation}

The target population of the study consisted of all adults in the Naluei Ward, local leaders and institutions that provide community-based adult education in Mongu District.

\section{STUdY SAMPLE}

In this case study, the sample consisted of eighty-six (86) subjects drawn from the target population. The sample comprised seventy (70) adult learner's in Naluei Ward, ten (10) local leaders like village headmen and senior traditional leaders known as area indunas, as well as six (6) institutions that provide community-based adult education in Mongu District. The institutions were the University of Zambia's Mongu centre for extension studies, Ministry of Community Development and Social Services, Ministry of General Education, Ministry of Agriculture, Development Aid from People to People Non-Governmental Organization and the Catholic Church.

\section{SAMPLing PROCEDURES}

Purposive sampling was used to provide conceptual richness (Victorino-Soriano, 2016) and a series of ten focus group discussions was convened in community locations. The focus group discussions were conducted in ten different village communities were community-based adult education was offered. Purposive sampling is used in research when a researcher intends to get detailed information from key informants. Purposive sampling seeks information-rich cases that can be studied in depth (Bailey, et al., 2011).

\section{RESEARCH INSTRUMENTS}

The quality of research depends, to a large extent, on the quality of the data collection tools. This study used a mixture of data collection instruments. Semi-structured interview guide, focus group discussion guide, field observation sheet and questionnaires were used to collect data. The questionnaires were used to collect data from leaders of institutions that provided communitybased adult education in Mongu District.

\section{Procedure of Data Collection}

To obtain the needed data from the sampled participants, the principal researcher got permission from the office of Mongu District Commissioner and the Barotse Royal Establishment authority to conduct research in the district and the Naluei Ward area in particular. In the field, consent was obtained from local leaders as well as respondents.

The researchers and research assistants administered semi-structured interviews, focus group discussions and a set of questionnaires. The study only used research assistants who could fluently communicate in both local Silozi language and English. The semi-structured interviews and focus group discussions were used to solicit data from adults in village communities. The focus group discussions were conducted at various schools where community-based adult education programmes where organized. The interviews and focus group discussions were recorded using a voice recorder. Questionnaires were used to collect data from leaders or representatives of institutions that provide community-based adult education in Mongu District. Field observations were guided by a check list to collect data pertaining to community-based adult education activities in the communities under study.

The composition of focus groups was diverse: including adult learners (past and current, male and female), family members of learners and local community-based adult education facilitators. All of the focus group discussions were approximately one hour in duration and endeavoured to elicit the participants' views on their experiences of community-based adult education, the benefits identified as a result of such participation as well as the challenges facing the on-going provision of communitybased adult education in the study area.

Ten in-depth semi-structured interviews (averaging approximately 45 minutes each) were also conducted with current and past adult learners, in order to examine and expand on issues emerging from the focus groups. As a result of the sampling strategy a total of 86 individuals participated in the study. 


\section{DATA ANALYSIS}

The purpose of data analysis is to process raw data for interpretation (Avoseh, 2000). According to Ogula (1995) data analysis is the process of reducing research data to manageable summaries. Quantitative data collected in this study was analyzed using the Statistical Package for Social Sciences (SPSS) in order to obtain frequencies and percentages. This data was summarized using descriptive statistics such as percentages and frequency distributions and was presented in tables. The SPSS was chosen for quantitative data because it helps to obtain frequencies and percentages in an accurate, precise, easier and fast way.

The views of subjects collected in qualitative data was organized in common themes and sub-themes and analyzed by way of narration. As a consequence of this process of data analysis, four overarching key themes were identified.

\section{FINDINGS AND DISCUSSION}

This section presents findings of the study in relation to the set objectives:

\subsection{Community-based Adult Education Activities in Naluei Ward}

From responses recorded during focus group discussions, interviews and completed questionnaires, the study established that there were a number of community-based adult education activities taking place in Naluei Ward of Mongu District in the Western Province of Zambia. The activities could be grouped into major programmes. These included basic and functional literacy, capacity building, sustainable livelihood education, lobbying and advocacy.

\subsubsection{Basic and Functional Literacy}

Just like many other rural parts of Zambia, Naluei Ward still have high illiteracy levels among youths and adult residents. Fortunately, the Ministry of Community Development and Social Welfare in collaboration with other stakeholders like Development Aid from People to People and the University of Zambia's extension studies have been striving to provide basic and functional literacy programmes depending on identified needs to various communities in the study area.

Although no certificate was given to participants, the study established that the youths and adults who participated in these programmes benefited a lot. Through interviews, focus group discussions and questionnaires' responses, it was established that learners with very low levels of literacy skills were offered some additional time, under the supervision of the facilitators, to learn and practice reading and writing in the local language. The central objective of the basic and functional literacy programmes offered in Naluei Ward are to promote equitable access to quality basic education while increasing participation and enabling youths and adults to acquire literacy skills and reach a sustainable proficiency level. They also acquire vocational and life skills which help them to improve their livelihoods and contribute to sustainable development. These programmes are cardinal in marginalized communities and vulnerable groups like women and differently abled persons.

Community-based participatory activities facilitated through adult education in Naluei Ward of the Western Province of Zambia help the youths and adults learn how to think by themselves, not what to think, to solve their problems using various activities. Critical thinking stimulated by communitybased adult education has helped community members how to think, plan, implement, monitor and evaluate various projects - job creation businesses and other activities that may contribute to sustainable development.

Apart from acquiring literacy and life skills, learners also learn an occupation, which not only serves as a motivation to enroll and stay in the programme, but also enables them to better support themselves and their families. This shows learners that learning is meaningful and can improve their living standards. Community-based adult education is one of major promising keys to enhance sustainable development in Zambia, Africa and probably the world at large. Community-based adult education can make us realize that Africa is the future. Africa has a great deal of world's human and natural resources (UNESCO, 2006). Community-based adult education has the potential to make us appreciate our local communities, our countries and make us understand the need to take full responsibility of our desired sustainable development. 


\subsubsection{Capacity-Building}

The study established that skills were enhanced through training in project development, vocational trades like various traditional crafts, rural development projects management, leadership, governance, livelihoods and income generation.

It was found out that community-based adult education links literacy and basic education to the issues of problem-solving and socio-economic development. Learners are empowered to discuss and analyze key issues in their communities and the community-based adult education programmes assist them in starting mini projects (such as income-generating activities) which may bring about social and economic change. Learners do not receive any certificate on the completion of the programmes, but with the literacy, vocational and life skills they have acquired, they might be able to rely on their own knowledge with positive attitude and continue with income-generating activities, which enable them to support themselves and their families.

\subsubsection{Sustainable Livelihood Education}

It was revealed that continuing education programmes for small-scale farmers and fishermen focusing on sustainable agriculture and fishing (including soil management, crop systems like cassava and cowpeas, pest/disease management, mitigating climate change effects, livestock management, aquaculture, home hygiene, community leadership and entrepreneurship/business development training) were offered to willing community members in Naluei Ward area.

In Zambia, and many other countries in Africa, most of the population still live in rural areas where the majority's livelihood depends on the natural resources like land, forests, wetlands and water (UNESCO, 2006). In order to have quality sustainable life that would enhance development, people in rural areas have to learn how to best use the natural resources for themselves and future generations. Indigenous communities in rural areas depend on their immediate environment to meet most of their basic needs. Community-based adult education plays a critical role to enhance sustainable use of natural resources in many African communities like Naluei Ward in the Western Province of Zambia. This would ensure that the environment was sustainably managed to produce food and other cardinal aspects of life for present and future generations.

The study also found out that financial literacy was also offered as part of sustainable livelihood education in Naluei Ward. This is cardinal as it might enhance individual, home and business management skills as well as inculcate a culture of saving for a 'rainy' day in one's future.

\subsubsection{Lobbying and Advocacy}

The study found out that there were a number of activities associated with lobbying and advocacy for the enhanced provision of community-based adult learning programmes. The lobbying and advocacy activities by community members and agents of change in Naluei Ward area encouraged both western and indigenous community-based adult education. The study established that the lobbying and advocacy activities in the study area were mostly done using interactive conversations, which may be called dialogue education between community members and agents of change like community development officers. This finding tallies with that of Victorino-Soriano (2016) in a study carried out in Philippines.

Dialogue education is a very important aspect of indigenous education system in many parts of Africa. As Banda et al., (2015) put it, indigenous knowledge system is a cardinal feature of community-based adult education in Africa. Adult education in Africa is intertwined with lifelong learning. Everyone should remember learning does not - and should not - stop when we reach adulthood. Community-based adult education can provide us with the knowledge, skills, attitudes, values and confidence we need to make life changing decisions or take us further in our life. We all learn new things every single day that contribute to our personal life, family life, community, professional and societal growth which help us become better at what we do to positively contribute to sustainable development.

\subsection{Participation Levels of Naluei Ward Community Members in Community-based Adult Education Programmes}

The second objectives of this study sought to find out the participation levels of community members in community-based adult education programmes in Naluei Ward of the Western Province of Zambia. 
Through focus group discussions, the study established that although community-based adult education was offered across Naluei Ward, striving to ensure equitable access to quality literacy and post-literacy programmes for youths and adults, participation levels by community members were still low. 'We are not asked what we want. They just tell us what they want to teach us,' bemoaned one elderly man during focus group discussion. One female youth expressed lack of resources to take part in the programme: 'We don't have ox-carts or bicycles to use to move from our villages to nearest schools where the programmes are organized'. Most youths indicated that many fellow youths were shy to learn together with older people. Many other respondents pointed out that they were usually busy with other activities and there seemed no reason to participate in adult literacy programmes as they were expected to provide for their families. Others bemoaned lack of information on the adult literacy programmes as one reason that also inhibited participation by some community members. Few senior citizens unfortunately expressed that they were too old to learn and felt shy to learn from the primary schools were their children and grand-children also learn from.

These findings were similar to what Owen (2000) and Sumbwa (2013) indicated that participation in adult literacy programmes was inhibited by the inaccessible nature of information about adult literacy programmes and the cost of participation, in most instances participation fee and distance to cover from homes to the centres where community-based adult education programmes where conducted. Participation of adult learners in community-based adult education activities is a key factor for the successful developments, implementation and evaluation of programmes. However, participation of the adult population in community-based adult education programmes has continued to pose a major challenge not only in Naluei Ward, but probably the world at large. As Sumbwa (2013) puts it, participation of adults and youths in literacy programmes is a basic step towards any form of adult learning, which is a process of lifelong learning and an entry point to the world of communication and information as well as cardinal to achieve sustainable development.

\subsection{Types of Community-Based Adult Education Activities in Naluei Ward}

The study revealed that only non-formal and informal community-based adult education programmes offered to social groups like women and youths were found in Naluei Ward. At the time of the study, there was no formal community-based adult education offered in the study area. Not even the Ministry of General Education was providing formal adult education in the study area. Table 1 summarizes the responses from providers of community-based adult education in the study area.

Table1. Type of community-based adult education provided by institutions

\begin{tabular}{|l|l|l|l|l|}
\hline Type of adult education provided & Formal & $\begin{array}{l}\text { Non- } \\
\text { formal }\end{array}$ & Informal & Percentage \\
\hline Ministry of General Education & 1 & 1 & 20 \\
\hline $\begin{array}{l}\text { Ministry of Community Development \& Social } \\
\text { Welfare }\end{array}$ & 1 & 1 & 20 \\
\hline Ministry of Agriculture & & 1 & 1 & 20 \\
\hline University of Zambia & & & 1 & 10 \\
\hline Development Aid from People to People & & 1 & 1 & 10 \\
\hline Catholic Church & $\mathbf{4}$ & $\mathbf{6}$ & 20 \\
\hline Total & $\mathbf{4 0}$ & $\mathbf{6 0}$ & $\mathbf{1 0 0}$ \\
\hline Percentage & & $\mathbf{1 0 0}$ \\
\hline
\end{tabular}

Source: Field data, 2016

However, during focus group discussions, there were a number of adults and youths who expressed that there was need to introduce programmes where learners could be given certificates upon completion of a programme such as entrepreneurship development or sustainable agriculture. According to Sundaram (2002), agriculture is the oldest, and arguably the most critical, industry in human history.

This finding is similar to that documented in the UNESCO global monitoring report on the progress towards attainment of Education for All (EFA) goals (see UNESCO, 2006). The report revealed that attainment of the EFA goals for literacy had been relatively neglected. According to the report published five years after 164 countries agreed on the Dakar framework for action, most attention had been devoted to the three EFA goals that concern the extension and improvement of formal elementary education systems. The other three EFA goals had been relatively neglected. The report 
attributed this neglect to the unfounded idea that primary education is more cost effective than youth and adult literacy programmes. Hence, in many countries, budget, loan and grant allocations to primary education were not in proportion to that of the adult education programmes.

\subsection{Challenges Faced by Community Members to Access Community-Based Adult Education}

The study established that there were a number of challenges that affected community-based adult education programmes in Naluei Ward. The major challenges given by respondents included poor funding to enhance implementation of projects learnt such as sustainable irrigation agricultural activities; bad terrain in most of the Western Province of Zambia makes it difficult for providers of programmes to reach some parts of the province; lack of motivated facilitators in some centres where community-based adult education activities where organized; and lack of resources by learners and would-be learners to participate in the programmes.

Further, the study revealed that adult learners' participation in community-based adult education programmes was not fully achieved because of high absenteeism rate and the programmes were held only two or three times a week. It is difficult to assess learners' attendance or dropout rates as their attendance is not recorded in most cases. Learners come to classes voluntarily. If they were absent for some time, they could still re-join the programme at any time.

\section{CONCLUSION}

The study's conclusion highlighted the urgent need to enhance community-based adult education in the study area. As the success of community-based adult education has not yet resulted in an equally successful implementation, it is time to take stock of what has been achieved, what has not yet been done and look at what should be done to achieve community-based adult education for all, not just a few. Community-based adult education is one of the keys needed to help people and their communities actively contribute to national sustainable development. It is a great concern that adult education is still not fully integrated into the education system in the study area, and probably the country at large.

Enhancement of community-based adult education is essential to enable and encourage adults in communities to acquire the knowledge, skills, positive attitudes, values and confidence necessary to play an active role in their personal life, working life, family life, business life and in general local communities' development.

\section{RECOMMENDATIONS}

The study recommends that although there were some community-based activities found in Naluei Ward of Mongu District, a lot can be done to enhance the provision of such programmes. Community-based adult education providers like government ministries and institutions like libraries, religious institutions, senior citizen centres, museums, social and fraternal organizations, business and industry, farmer institutes, community colleges, state and regional universities, vocational and technical institutions, health related organizations, the mass media, to name a few, are positioned to assist in the design and development of community-based lifelong learning communities and the provision of continuous learning opportunities through community-based adult education.

Similar studies should be done in other districts of Zambia for comparison purposes and to allow for generalization of findings on the aspects of community-based adult education activities in the country.

\section{REFERENCES}

[1] Avoseh, M. B. M. (2000). 'Adult Education and Participatory Research in Africa: In Defence of Tradition'. Canadian Journal of Development Studies (pp. 565-575), Volume XXI.

[2] Ayot, R.M. (1999).Community Education and Development. Nairobi: Educational Research and Publications.

[3] Bailey, N, Ward, M, and Goodrick, M. (2011). Sowing the Seeds of Social Change. The Outcomes and Impact of a Social Action Model of Community Education. Accessed on 27/07/16 from: http:// www.aontas.com/download/pdf/sowing_the_seeds_of_social_change.pdf.

[4] Banda, S., Namafe, C.M., \& Chakanika, W.W. (2015). 'Traditional environmental knowledge among Lozi adults in mitigating climate change in the Barotse plains of Mongu District, Western Zambia.' International Journal of Humanities Social Sciences and Education (IJHSSE) (pp 222-239), Volume 2, Issue 9, September 2015. ISSN 2349-0373 (Print) \& ISSN 2349-0381 (Online) http://www.arcjournals. org.

[5] Banda, S. (2011). 'The Role of Dialogue Education in Ensuring Environmental Sustainability in Petauke District, Zambia'. Journal of Humanities (pp. 12-38), Volume 11. Lusaka: University of Zambia Press. 
[6] Compton, J., \& Mc Clusky, H. (1980). 'Community education for community development.' In E. Boone, R. Shearon, E. White, \& Associates, Serving Personal and Community Needs through Adult Education (pp. 247-249). San Francisco: Jossey-Bass.

[7] Dale, E., \& Tyler, R. (1934). 'A Study of the Factor Influencing the Difficulty of Reading Materials for Adults of Limited Reading Ability.' In W. H. Dubay (Ed.), Unlocking Language: The classic readability studies (pp. 80-107). California: Impact Information.

[8] Dave, R. (Ed.). (1976). Foundations of Lifelong Education. Oxford: Pergamon.

[9] Friere, P. (1986). Pedagogy of the Oppressed. Harmondsworth: Penguin.

[10] Gboku, M. (2007). Developing Programmes for Adult Learners in Africa. Gaborone: Creda Communications.

[11] Hamilton, E., \& Cunningham, P. (1989). 'Community-based adult education.' In S. Merriam and P. Cunningham (Eds.). Handbook of Adult and Continuing Education (pp. 439-450). San Francisco: JosseyBass.

[12] King, E. (2013). 'Learning for all: The World Bank group learning strategy 2020.' Adult Education and Development (pp. 34-36), Volume 80. Bonn: DVV International.

[13] Mtonga, H.L. (2016). 'Adult education is many things; its meaning and implications.'Journal of AdultEducation (pp. 15-20). October 2016, Vol. 2 No. 2. Lusaka: University of Zambia Press.

[14] Noyoo, N. (2008).Social Policy and Human Development in Zambia. Lusaka: University of Zambia Press.

[15] Ogula, P.A. (1995). A Handbook on Educational Research. Nairobi: New Kemit Publishers.

[16] Owen, T. (2000). Men on the Move: A Study of Barriers to Male Participation in Education and Training Initiatives. Dublin: Aontas.

[17] Power, M., Neville, P. \&O’ Dwyer, M. (2011). Assessing the Social Value of Community-based Adult education. Limerick: LCEN, LCAES, PAUL Partnership \& Limerick Regeneration Agencies. Accessed on from: http://www.limerickcityaes.ie/LimerickAESSite/files/73/730610cc-8ad5-4162-9b9b-8ec4f0692036. pdf.

[18] Salling Olesen, H. (1989). Adult Education and Everyday Life. Roskilde: Roskilde University.

[19] Smith, R. (1982). Learning How to Learn. New York: Cambridge.

[20] Sumbwa, P.I., (2013). 'Where are the men? These are the reasons they are not interested in literacy.' Adult Education and Development (pp. 100-104), Volume 80. Bonn: DVV International.

[21] Sundaram, S. (2002). Rural Development. Mumbai: Himalaya.

[22] UNESCO, (2006). EFA Global Monitoring Report: Literacy for Life.Paris: UNESCO.

[23] Victorino-Soriano, C. (2016). Community-based Lifelong Learning and Adult Education: Adult skills and competencies for lifelong learning. Paris: UNESCO. ISBN: 978-92-9223-568-0 (print version); ISBN: 978-92-9223-569-7 (electronic version).

[24] Wain, K. (1987). Philosophy of Lifelong Education. London: Croom Helm.

[25] Yin, R.K. (2014). Case Study Research: Design and methods. (5 ${ }^{\text {th }}$ edition). California: Sage Publications.

\section{AUTHORS' BIOGRAPHY}

Dr Stephen Banda, is a lecturer and researcher in the Department of Adult Education and Extension Studies at the University of Zambia. He is also Resident Lecturer for Western Province. His areas of interest in research are environmental adult education, community development and planned change.

Anolt L.H. Moonga, is a lecturer and Head of the Department of Adult Education and Extension Studies at the University of Zambia.

Phyllis I. Sumbwa, is a lecturer in the Department of Adult Education and Extension Studies at the University of Zambia. She is also a Resident Lecturer for Lusaka Province.

Citation: Stephen, Banda et al. "Aspects of Community-based Adult Education Activities in Naluei Ward of Mongu District, Zambia." International Journal of Humanities Social Sciences and Education (IJHSSE), vol 4, no. 11, 2017, pp. 43-56. doi:http://dx.doi.org/10.20431/2349-0381.0411005.

Copyright: ( $) 2017$ Authors. This is an open-access article distributed under the terms of the Creative Commons Attribution License, which permits unrestricted use, distribution, and reproduction in any medium, provided the original author and source are credited. 